\title{
Does NGOs' Commercialization Affect Volunteer Work? The Crowding out or Crowding in Effect
}

\author{
Paweł Mikołajczak ${ }^{1}$ (D) Piotr Bajak ${ }^{2}$
}

Published online: 26 June 2020

(C) The Author(s) 2020

\begin{abstract}
The aim of this article is to identify whether the commercialization of NGOs has an influence on the crowding out or crowding in effect of volunteer work, and to indicate the factors affecting volunteers' regular involvement in NGO activity. The conducted research confirmed the hypothesis that the commercialization of Polish NGOs is associated with the crowding in effect of volunteer work. The authors prove that the direction of knowledge transfer can be important in engaging volunteers to work in NGOs. The model demonstrates that the likelihood of the NGO crowding in effect increases with frequent internal training, and decreases rapidly with participation in conferences, which work as external knowledge transfer.
\end{abstract}

Keywords NGOs · Crowding out/in effect · Volunteer, commercialization, knowledge transfer

JEL L $31 \cdot \mathrm{P} 31 \cdot \mathrm{O} 15 \cdot \mathrm{J} 29$

\section{Introduction}

There is general agreement in the literature that voluntary work is of substantial economic value. In non-profit organizations in particular, voluntary work is a critical resource, and volunteer management is a central part of human resource management.

Paweł Mikołajczak

pawel.mikolajczak@ue.poznan.pl

Piotr Bajak

bajak.p@gmail.com

1 Department of Money and Banking, Poznań University of Economics and Business, Aleje Niepodległości 10, 61-875 Poznań, Poland

2 Polish Economic Society, ul. Nowy Świat 49, 00-042 Warszawa, Poland 
Volunteer management is intended to increase the sum of services provided by volunteers and to improve the matching between the volunteers and the organization. Choosing a career in the form of volunteering seems to be something special. Many believe that this is due to exceptional sources of internal motivation, such as the need to be involved in public service. Rosen and Sims (2011) indicate that altruistic behavior in adulthood is a consequence of childhood charity, rooted in family and education. Over time, a better understanding of the purpose of the work only strengthens this individual motivation. However, this is best done in non-profit organizations, whose unique culture and effectiveness in solving social problems offer a space where the team's pride mixes with their personal sense of achievement.

European research indicates that even though there has been a general increase in the number of active volunteers and voluntary organizations in the EU over the past 10 years, significant difficulties are observed. For example, 93\% of respondents indicated that they have never volunteered abroad. The survey also suggests that more than half $(54 \%)$ of the young people who had taken part in organized voluntary activities did not incur any expenses, a further $28 \%$ of respondents incurred expenses without receiving any compensation, and one in six respondents (16\%) were compensated for their expenses (Katsarova, 2016). The main difficulties seem to be related to the changes that are affecting the nature of voluntary engagement. They are also associated with a mismatch between the needs of voluntary organizations and the aspirations of the new generations of volunteers, rather than a drop in the number of volunteers. Factors include inadequate knowledge of the needs of organizations, the difficulty in matching volunteers with appropriate organizations, preference for short rather than long-term voluntary commitments, and increases in the number of voluntary organizations resulting in volunteers being spread across an ever-larger number of organizations.

The decrease in the number of volunteers is particularly visible in the US, where volunteerism plays a significantly larger role in American civic life than it does in other countries. Research indicates that Americans are 15\% more likely to volunteer their time than the Dutch, 21\% more likely than the Swiss, and 32\% more likely than Germans. As Dreyfus (2018) remarks, according to the Bureau of Labor Statistics, volunteerism peaked between 2003 and 2005. From this time the percentage of Americans who report having volunteered decreased from $28.8 \%$ to $25.3 \%$. The volunteering rate has slowly declined from $29 \%$ to $25.4 \%$ in just 10 years (School of Public Policy, 2018; Gordy, 2015). It is widely acknowledged that the non-profit sector must reverse these trends and do more to increase the engagement of communities. This is particularly necessary in the human services sector, which relies heavily on the support of volunteers to fill the gaps in federal, state and local funding (Dreyfus, 2018). Volunteer indicators in the US have been declining since 2010, as they have in Australia (Huntley, 2019) and Canada (Turcotte 2015). The above numbers have raised concerns among researchers, and have prompted them to conduct research focused on finding the causes of this phenomenon.

From the perspective of non-profit organizations, the role of the volunteer is particularly important, not only because of their complementarity with staff shortages, but also from the point of view of solicitude for a social mission. When non-profit organizations engage in activities aimed at generating commercial revenue to provide additional funds for fulfilling their mission, they must at the same time take particular 
account of the perception of volunteers in order to avoid tensions. While paid staff might be market driven, volunteer motivations are social mission driven.

Although there is an intense discussion in the literature on non-profit organization commercialization, which may trigger a variety of tensions in organizations (e.g. mission drift), so far, the problem of the influence of commercialization on voluntary work has been poorly verified empirically. The identified research gap therefore provided a challenge for the author. Knowledge of the relationship between commercialization and the ability of an organization to attract volunteers is crucial for an NGO's performance. Even if the commercialization of non-profit organizations does not crowd out volunteer work, and, contrary to the speculations of other researchers does not cause significant tensions along with the resulting difficulties in retaining volunteers in the organization, it is necessary to find out which tools for motivating volunteers increase the probability of maintaining an appropriate level of volunteer retention in commercialized NGOs. Firstly, the question arises whether commercialization causes a crowding out or crowding in effect with regard to volunteer work. The second question is what factors affect volunteer work as part of an NGO's activity.

Answers to these research questions will improve knowledge about the sector and give an indication as to the way NGOs should develop, while also providing practical implications for their governance and operations. Thus, the aim of this article is to identify whether the commercialization of NGOs influences the crowding out or crowding in effect with regard to volunteer work, and to indicate the factors that affect volunteers' regular involvement in an NGO's activity. The article presents a hypothesis which assumes that commercialization of NGOs determines stronger voluntary work in the functioning of such NGOs.

To achieve the paper's aim, ANOVA analysis and logistic regression were carried out on 1300 NGOs, including 200 NGOs that conduct business activity.

\section{Literature Review}

\section{Tensions of Non-profit Commercialization}

Commercialization is the process in which non-profit organizations engage in activities aimed at generating commercial revenues (Simpson and Cheney, 2007; Dart, 2004). As a response to institutional changes, the non-profit sector is increasingly performing business activities, and adopting market values and methods in the process of managing and providing services (Eikenberry and Kluever, 2004). The purpose of the commercialization process is to strengthen the economic stability of the organization by obtaining revenues independent of funding from government and private donors (Mikołajczak, 2020; Ebrahim, 2003). As emphasized by Salamon (1987), this is an attempt to adopt non-profit market behavior. At the same time, it is the reluctant response of social organizations to falling revenues from public funds and private donors, and to a change in the legal conditions in the non-profit sector. In turn, Evans et al. (2005, p. 73), perceive commercialization as part of a neoliberal method of nonprofit management.

Non-profit organizations usually complete their mission by financing their activities with funds from public subsidies or from individual and commercial donors. Their 
capabilities in this regard depend primarily on their reputation, reliability and effectiveness (Barr et al., 2005). Hence, non-profit organizations must rely on many different sources of support in order to successfully fulfil their social mission. Increasingly, these entities engage in commercial activities involving the sale of products and services. Therefore, in order to raise funds, they are combining social activity with economic activity (Mikołajczak, 2019; Maier et al., 2016).

The essence of the NGO commercialization process is to build the economic stability of the organization by becoming independent of subsidy based and/or philanthropy funding, as well as by making changes in the area of organization management, emphasizing its entrepreneurship and self-sufficiency (Foster and Bradach, 2005). In a broader sense, commercialization of the NGO sector is related to the state's social policy and the limited possibilities the state has of financing the activities of such entities (Kerlin and Pollak, 2006). This is also determined by the growing number of people in need of support and the growing number of organizations competing for funding for their activities (Boschee, 1998).

A literature search identifies several leading problems arising from the commercialization of non-profit organizations. These mainly concern the tensions related to the impact of commercialization on mission drift, the crowding out of public aid and/or the activity of private donors through commercial revenues, as well as distortions in stakeholder perceptions of legitimacy.

Researchers emphasize that the threats associated with mission drift arise from the danger of social activity becoming dominated by economic activity, and thus the transformation of a social organization into a commercial enterprise, to the detriment of the achievement of its social goals and values (Powell and Owen-Smith, 1998; Tuckman, 1998). Other authors indicate that commercialization should be associated with a narrower, instrumental orientation of the NGO mission (Foster and Bradach, 2005). Ebrahim (2003) also points to the risk of departing from the organization's original primary mission to attract available funds and ensure financial stability. The author emphasizes that NGOs are starting to focus more on survival goals than on fulfilling their original mission. According to researchers, this problem arises in particular when NGOs engage in commercial activities.

In addition, based on research conducted in developed countries, some authors claim that commercial activity diverts the real attention of NGOs towards activities unrelated to their original mission, requiring the involvement of professional, technical and personnel infrastructure (e.g. Ebrahim et al., 2014). In turn, some authors believe that commercialization of the non-profit sector may stimulate the formation of NGOs that focus on strict program performance assessments, while reducing their involvement in direct activity focused on social change (Marshall and Suárez, 2013). Foster and Bradach (2005) argue that commercial priorities can distract non-profit organization managers from their key social missions, and sometimes even subvert those missions. D'Espallier, Hudon, and Szafarz (2017), using a worldwide sample of 1151 MFIs (Micro Finance Institution) providing poor people with cheap micro loans, found that interest rates increase with aid volatility, while average loan size (ALS) is inversely related to aid volatility.

Commercialization critics also argue that when non-profit organizations taking on entrepreneurial behavior, they reduce the willingness of private donors to become active, thus weakening their ability to raise additional funds for the organization's 
mission (Kerlin and Polak, 2011; Mikołajczak, 2018). Other researchers argue in a similar vein, pointing to the effect of the crowding out of public aid by commercial activities (Enjolras 2002).

From a financial perspective, the dual nature of the activities of commercialized nonprofit organizations makes them use a wide spectrum of different sources of revenue e.g. public subsidies, funds from private donors or commercial sales of products and services. However, the requirement of cost internalization means that they generate lower profits than could have been generated if they assumed the full economic costs. Moreover, double-pricing strategies, which result in lower revenues, limit the competitiveness and attractiveness of commercialized organizations for financial institutions and social investors (...).

Controversies related to commercialization arise from the tensions created when organizations seek different and contradictory goals, or try to meet the inconsistent requirements of many stakeholders (Smith and Lewis, 2011). Aside from mission drift, stakeholder perceptions of legitimacy and crowding out of public support, some researchers include in these tensions weakening retention of volunteers as a result of the process of non-profit commercialization.

In an organization the role of volunteer is particularly important, not only because of their complementarity with staff shortages, but also from the point of view of solicitude for a social mission. Austin et al. (2006) explain that the reluctance to accept commercialization can affect both a volunteer's motivation, and the relationship of volunteers with other staff. While paid staff might be market driven, volunteer motivations are social mission driven. For volunteers, a choice of career in the form of volunteering is something special. Many believe that this arises from exceptional sources of intrinsic motivation, such as the need to be involved in public service. Thus, market goals might be difficult to accept, and to some extent are a catalyst to the loss of volunteers' commitment to an organization. Moreover, unlike paid employees, who might be expected to comply with managerial demands, volunteers are free to withdraw their labor if they disapprove of the strategic direction the organization is pursuing (Royce 2007). Leaders responsible for managing a non-profit organization must keep this in mind in order to avoid tensions between organization stakeholders with regard to leadership, employee relations, recruitment and culture. They must also manage relationships between employees and volunteers in order to achieve retention of the latter at an appropriate level (Liu and Ko, 2012). A lot of analyses assume that, unlike paid staff, volunteers receive limited training, possess no disciplinary knowledge, and have little power even if their work has a crucial social impact. This may cause frustration and tensions (Ganesh and McAllum, 2012). As Weisbrood (1997) said "volunteer time is important but not easily substituted for money".

\section{Crowding out/in of Volunteer Work}

\section{Public Support}

When considering the effect of the crowding out of volunteer work, the literature focuses on two approaches. The crowding out of volunteers by public sector activity was well recognized. Hackl et al. (2012) empirically identified three channels for the crowding out of voluntary labor. Firstly, an increase in public social expenditure 
decreases the probability that the individual will volunteer (fiscal crowding out). Secondly, political consensus between individuals and the government also induces volunteers to reduce their unsalaried activities (consensual crowding out). And finally, the more a government supports democratization, the lower the individual's engagement (participatory crowding out). Religiosity and a more unequal income distribution in a country increase individuals' willingness to volunteer. This was also confirmed by Suzuki (2017), who proved that cuts in government expenditure have been complemented by an increased involvement of Japanese citizen organizations in voluntary activities. However, Duncan (1999) did not confirm empirical support for crowding out in the relationship between government spending and volunteering. Also, Van Oorschot and Arts (2005) did not find evidence on the crowding out effect of public expenditure on volunteering. Simmons and Emanuele (2004) found a small crowding out effect on volunteer engagement as a result of US support, however the authors explained that governmental expenditure emphasizes the ideals of volunteering and makes volunteering more attractive. In turn, the positive impact of Canadian government expenditure on the decision to volunteer proved the Day, Canadian, Day and Rose (1996) hypothesis. Bartels et al. (2013) proved that volunteering is likely to decline when government intervention is decreased. The authors recommended a collaborative approach to sustaining volunteering (Andreoni and Payne, 2011). Although there exists a large body of literature investigating the influence of government spending on volunteers' involvement in which empirical evidence on the crowding out effect is still ambiguous, there is very little research on the relationship of commercial revenues on determining private donations of time. The findings of scholars in this regard are presented below.

\section{Commercial Revenues}

Noticeably little research has been devoted to the relationship between commercialization and volunteer work. Enjolras (2002) explored the impact of commercialization on voluntary work at the organizational level in Norwegian voluntary sport organizations. The author assumed that commercialization may not crowd out voluntary work when it is used to generate commercial resources that in turn are used to produce mission-related good. He pointed out that if individuals value the collective good, volunteers have the incentive to contribute by working voluntarily. This situation should lead to a relationship where increased commercial income is associated with increased voluntary work. Based on 218 organizations, the researcher proved that voluntary work constitutes an input for the generation of commercial income in Norwegian non-profit organizations. The author notes that voluntary work and commercial income are not substitutes but are complementary.

Maier et al. (2016) suggest that an NPO's (Non-profit organization) marketization is associated with commercialization of relationships which may, but need not, involve the introduction of monetary exchanges, for instance, when volunteering becomes an instrumental exchange of work in return for personal gratification. However, the authors point out that at the same time NPOs may also become more business-like in their selection of personnel, which is reflected in the concept of professionalization. This may lead to consequences that range from raising volunteers' qualification levels 
to employing more paid staff and placing stronger emphasis on formal educational credentials.

Guo (2006) explored the causality between commercialization and organization performance (e.g., the ability to attract donors and volunteers). On the basis of 155 non-profit organizations, including 67 venturing non-profit organizations, he pointed out that commercial revenues do not make a significant contribution to the organization's ability to crowd in volunteers. At the same time, he found that the effects of commercialization on the ability to attract and retain qualified staff differ between fields of activity, and have a positive outcome in human service NPOs.

For Geoghegan and Powell (2006), commercialization is associated with the use of more paid work and unchanged amounts of voluntary work. However, it entails a qualitative change to volunteering, which means that volunteers are involved in ancillary tasks, whereas central tasks are performed by paid staff. Herman and Rendina (2001) proved that there is a relatively small percentage of volunteers who participate in commercial activities. The researchers explained that the use of activities that are consistent with or advance the organization's mission is approved of, while the use of commercial activities that do not advance the mission is generally disapproved of.

\section{Research Methodology}

The main hypothesis formulated was that the commercialization of Polish NGOs is associated with the crowding in effect on volunteer work. Data for the present analyses was acquired from the Klon/Jawor Association, which partly commissioned research for the Kantar Millward Brown company in 2018 to conduct a national survey on a representative sample of 1100 Polish foundations and associations. The research was carried out on a random group of associations and foundations drawn from the Polish Statistics REGON register. A CAWI study was carried out by the Klon/Jawor Association. The organizations selected for the study received emails inviting them to join the research, and were additionally reminded and encouraged to participate in the study by phone. 200 organizations in Warsaw were examined by Kantar Millward Brown on behalf of the office the capital city of Warsaw (using the same questionnaire as in the CAWI survey).

The data concerning associations and foundations was collected by means of the interview method, which used two research techniques: 1) 1100 interviews were carried out employing the CAWI technique (through an on-line questionnaire completed by the organizations themselves. The CADAS technique was used for this study), 2) 200 were carried out employing the CAPI technique (direct computer-assisted personal interviews, conducted by interviewers in the area). In both cases, the respondents were people performing key functions in their organizations. Therefore, the questionnaire was to be completed by the leader of the organization, a member of the senior management, or a member of the trustee board or management committee. The data was collected in compliance with the principle of confidentiality.

Contact details for the organizations were obtained from spis.ngo.pl, which was verified and supplemented with data available on the Internet and information from local proxies for NGOs. The CAWI survey was carried out between May and 
September 2018. The CAPI survey was carried out between October and December 2018.

To achieve the paper's aim, ANOVA analysis and logistic regression were carried out. To achieve the paper's goal in identifying differences in the functioning of NGOs that cause a crowding in or crowding out effect, a one-factor analysis of variance (ANOVA) was carried out. ANOVA analysis of variance is a statistical method used to study observations that depend on one or more simultaneously acting factors. This method indicates which factors can be the reason for differences between the group means observed.

In this one-factor variance analysis, distribution normality research was conducted with the help of a Kołmogorow-Smirnow test. For those variables which did not meet the distribution-normality criteria in the analysis, a non-parametrical Kruskal-Wallis test was carried out. To check the assumption of variance homogeneity, a BrownForsythe (B-F) test was performed due to unequal group sizes. In cases where the variance-homogeneity criterion was met, an F-test was conducted to assess the differences. In other cases, a Welch test was employed to calculate the averages. Dichotomic variables include social enterprises and NGOs that do not run commercial activities. At the same time, dependent variables were selected on the basis of a literature review. Dependent variables were marked from V1 to V3, characterizing volunteer involvement.

The logistic regression model developed for the purpose of this paper is aimed at defining the probability of an NGO's crowding in effect, depending on the five selected variables presented in Table 2 . An attempt has been made to quantify and parametrize the likelihood of an NGO's crowding in effect occurring. Therefore, variables were used regarding the involvement of volunteers in NGOs in the survey. The possibility of predicting an NGO's crowding in effect was defined as the probability, on the basis of survey results, of an NGO falling into one of two binary classes ( 0 - use of the work of volunteers did not take place, 1 - NGOs did use the work of volunteers).

To verify the main hypothesis assuming that the commercialization of Polish NGOs is associated with a crowding in effect on volunteer work, the multiple logistic regression model applied in the studies made it possible to determine the probability of belonging to one of the two classes. The multiple logistic regression method was used to assess the risk of an NGO's crowding effect, to indicate its determinants and to assess the impact of selected factors on the NGO's support for volunteers.

\section{Results}

To identify differences in the crowding in or out effect of social enterprises or NGOs not performing business activity, a one-factor analysis of variance (ANOVA) was carried out. At the first stage, distribution-normality research was conducted for all dependent variables, with a level of $p<0.01$ reached in a Kołmogorow-Smirnow test, which gave grounds for rejecting the hypothesis about the distribution normality of the variables tested. As the condition of distribution normality for dependent variables was not met, a non-parametrical Kruskal-Wallis test was employed to compare average survey values. For the K-W test, the level of variable significance between V1 and V2 was smaller than $p=0.05$, so grounds were given for rejecting the assumption of the 
lack of significant differences among average results between NGOs that perform and those that do not perform business activity.

To check the assumption of variance homogeneity, a Brown-Forsythe test was used due to unequal group sizes (200 NGOs conducting business activity and 1100 not doing so; data shortages were tackled by not including the NGOs concerned in the analysis). The assumption of variance homogeneity was not met for all variables $(p<0.05)$, and a Welch test was employed to evaluate averages. The variance analysis showed statistically significant differences in the way NGOs perform or do not perform business activity with regard to all variables (see Table 1).

To establish which factors are significant and influence the crowding effect, stepwise backward regression was carried out. The logistic regression analysis - where the explanatory variable was a binary variable, that is the commercialization of nongovernmental organizations, and the explanatory variables were public external financing, private external financing and private internal financing - indicates that all variables determine the probability of an NGO's commercialization. The model achieved the value of the $\chi^{2}$ test at the level of 20.37, with a $p$ value of 0.01 , which means that it is statistically significant. The model also accurately reflects actual data (the HosmerLemeshow test indicates a $\mathrm{p}$ value of 0.63 ). Therefore, the hypothesis that the commercialization of Polish NGOs is associated with the crowding in effect on volunteer work was confirmed.

The parameters of the variables obtained - the values of directional coefficients and related $p$ values, the odds ratio and the VIF coefficient - are presented in Table 2.

As part of the model, two variables were selected with reference to the likelihood of an NGO's crowding in effect, internal training - conducted by people from the organization - and conferences (their $\mathrm{p}$ values are less than 0.05 ). Collinearity analysis suggested the lack of a problem of correlating independent variables, as the VIF factor for the variables was not greater than 1.40 .

Table 1 ANOVA analysis

\begin{tabular}{|c|c|c|c|c|c|c|}
\hline Assessment category & $\begin{array}{l}\text { NGOs } \\
\text { conducting } \\
\text { business } \\
\text { activity }\end{array}$ & $\begin{array}{l}\text { NGOs } \\
\text { not } \\
\text { conducting } \\
\text { business } \\
\text { activity }\end{array}$ & $\begin{array}{l}\text { Kruskal- } \\
\text { Wallis- } \\
\text { Test Value }\end{array}$ & $\mathrm{p}$ & $\begin{array}{l}\text { Welch- } \\
\text { Test } \\
\text { Value }\end{array}$ & $\mathrm{p}$ \\
\hline & \multicolumn{6}{|c|}{ Average value } \\
\hline $\begin{array}{l}\text { V1: Participation of volunteers in the work } \\
\text { of the organization }\end{array}$ & $69 \%$ & $61 \%$ & 8.06 & 0.01 & 8.76 & 0.00 \\
\hline $\begin{array}{l}\text { V2: Number of volunteers even once } \\
\text { involved in the organization's activities } \\
\text { in the last } 12 \text { months }\end{array}$ & 150 & 22 & 14.01 & 0.00 & 6.40 & 0.01 \\
\hline $\begin{array}{l}\text { V3: The number of volunteers involved in } \\
\text { the organization's activities are involved } \\
\text { in the work of the organization regularly } \\
\text { and often (at least once a month) }\end{array}$ & 86 & 48 & 10.10 & 0.01 & 1.69 & 0.20 \\
\hline
\end{tabular}


Table 2 Parameters of independent variables of the logistic regression model

\begin{tabular}{lcccr}
\hline Assessment category & Coefficient & VIF & p & ORi \\
\hline W1: Size of NGO & -0.088 & 1.09 & 0.18 & 0.92 \\
W2: Internal training - conducted by people from the organization & 0.994 & 1.18 & 0.00 & 2.70 \\
W3: External training - by people outside the organization & -0.102 & -0.102 & 0.74 & 0.90 \\
W4: Conferences & -0.718 & 1.4 & 0.03 & 0.49 \\
W5: Consultations, consultancy, meetings with specialists & -0.026 & 1.35 & 0.95 & 0.97 \\
\hline
\end{tabular}

The model is therefore described by the following formula:

$$
C=\frac{\exp (1.815+0.994 W 2-0.718 W 4)}{1+\exp (1.815+0.994 W 2-0.718 W 4)}
$$

where:

C - probability of crowding in effect occurring,

W2 - internal training - conducted by people from the organization,

W4 - conferences.

The logistic regression analysis demonstrated that:

- $\quad$ offering volunteers acquisition of knowledge inside the organization provided by internal training - conducted by people from the organization - caused an increase in the probability of an NGO's crowding in effect, as its directional coefficient is 0.994 ,

- enabling participation in conferences works in the opposite direction, resulting in a slight decrease in the likelihood of an NGO's crowding in effect, as its directional coefficient is -0.718 .

- it can be said that the size of an NGO, external training - by people outside the organization - and consultations or meetings with specialists do not influence the crowding out or crowding in effect, as the $p$ value is $>0.05$.

The model demonstrates that the likelihood of an NGO's crowding in effect increases with frequent internal training and decreases rapidly with providing participation in conferences, which works as an external knowledge transfer.

To verify the predictive power of the constructed probability model of an NGO's crowding in effect, the error matrix method was used, the results of which are presented in Table 3.

Table 3 Matrix of errors developed for model C

\begin{tabular}{llcc}
\hline Item & & \multicolumn{2}{l}{ Observed real classes } \\
\cline { 3 - 4 } & & Positive & Negative \\
\hline Predicted decision classes & Positive & 127 & 53 \\
& Negative & 11 & 9 \\
\hline
\end{tabular}


The number of true-positive cases (TP) is 127 observations, and of false-positive cases (FP) - 53 observations. The number of true-negative cases (TN) is 9 , and of falsenegative ones (FN) - 11. To assess the model's predictive capabilities, the results of the error matrix and the following coefficients were used: precision (PPV), negative predictive value (NPV), likelihood ratio (LR), efficacy (ACC), sensitivity and specificity. The results are shown in Table 4.

The model correctly identifies two out of three NGOs (the accuracy of the PPV classification was calculated at $70.46 \%$ ). The probability that the organization was classified as commercialized with a negative result is $45.16 \%$ (NPV). The ratio between the chance that a positive result of the $\mathrm{C}$ test will be achieved by NGOs from the group of those who have been commercialized, and the likelihood that the same effect will be observed among organizations that have not been commercialized is 1.08 (LR). The effectiveness of $\mathrm{C}$ (ACC) is $67.95 \%$, which means that the model correctly shows 6 out of 10 cases of commercialized NGOs. The ability of the $\mathrm{C}$ test to detect commercialization in the analyzed group of commercialized organizations (sensitivity) is $92.09 \%$. On the other hand, specificity, i.e. the ability of the $\mathrm{C}$ test to exclude noncommercialized organizations, is $14.43 \%$.

\section{Discussion}

Foster and Meinhard (2002) indicate that since government support for social and cultural services has decreased significantly over the past few years, social organizations have tried to avoid limiting their services by relying more on volunteers. These volunteers have made it possible for NGOs to provide services, or have helped them to raise funds for their activities. Hopkins (2002) also argues that the decrease in public support is accompanied by an increase in the number of service orders carried out by non-governmental organizations in which volunteers are involved. Similar observations were formulated by Graff (2006), which stressed that the lack of financial resources continues to be an important issue for the non-profit sector in the twenty-first century. The involvement of volunteers is playing an increasingly important role and is becoming the norm for organizations in this sector.

Thus, if limiting government funding is the cause of both commercialization (McKay et al. 2015; Guo, 2006) and the greater involvement of volunteers in organizations (Hackl et al. 2012; Suzuki, 2017; Simmons and Emanuele 2004), it can be assumed that these two processes may occur simultaneously or strengthen each other.

Table 4 Assessment of the model's predictive abilities

\begin{tabular}{lc}
\hline Item & Value \\
\hline PPV & $70.46 \%$ \\
NPV & $45.16 \%$ \\
LR & 1.08 \\
ACC & $67.95 \%$ \\
Sensitivity & $92.09 \%$ \\
Specificity & $14.43 \%$ \\
\hline
\end{tabular}


The similarity of the reasons for commercialization and greater involvement of volunteers can also alleviate the negative perception of volunteers towards the commercialization of NGOs indicated by various researchers (Herman and Rendina, 2001; Ganesh and McAllum, 2012). Although the motives for commercialization have a financial dimension and volunteers are purely altruistic, the overriding goal of commercial fundraising and volunteer work is convergent - the implementation of a social mission. Proper exposure to coexistence or convergence of interests may be the key to suppressing any tensions arising from the skepticism of volunteers towards commercial behavior.

However, it is difficult to ignore the evidence in the literature that organizations are choosing to use fewer volunteers due to the increased costs of volunteering (Handy and Srinivasan, 2005; Sajardo and Serra, 2011).

Graf 2005 emphasizes that rising non-profit management standards require greater resource allocation for volunteers (including training programs; supervision, training and cognitive materials, etc.) New volunteers require orientation about the organization, its mission, values and activities, as well as specific training in a given field. In highly responsible or high-risk positions, initial and continuing training can be extensive. Volunteers need daily support and supervision to ensure that performance, safety, quality of service and satisfaction standards are achieved. The findings in our research confirm these findings.

Mook et al. (2007) emphasize that although volunteer work is free for entities using this service, it involves implied costs for non-profit organizations in terms of recruitment, training and employment. Similar observations are made by Graff (2006), who points out that more and more often non-profit organizations rely on the work of volunteers in performing important tasks, which limits their human resource costs by reducing wage expenditure. On the other hand, such a strategy requires increased expenditure on recruitment, training and volunteer management. This is especially important for non-profit organizations that seek to reduce costs while increasing their level of professionalism and overall performance. Many NPOs recognize that they cannot provide their services and conduct their activities without volunteer contributions (Cordery and Tan, 2010).

The commercialization of NGOs often involves the use of professional motivating instruments. This can be an important argument for a non-profit organization in stimulating the attractiveness of the organization in the perception of volunteers and increasing the efficiency of its operations. Confirmation of such argumentation, in addition to the results of this study, can be found in the work of Manetti, Belucci, Como and Bagnoli (2014) examining the methods of measuring the social returns of volunteer recruitment, training, and management. The authors indicate that while trying to reduce their costs, NPOs are making an effort to increase their levels of professionalization and overall efficiency. Handy and Mook (2011) prove that a factor motivating volunteers to get involved, apart from the "warm glow", are numerous private benefits, including knowledge and skills acquired through work and training.

\section{Conclusions}

A search of the current literature on volunteers indicates that this area is very topical for both scholars and practitioners. As one of the most important resources of non-profit organizations, volunteers often condition the effective fulfillment of the mission of such 
organizations. Volunteering itself is a symbol of the activities of these entities. However, recent research indicates that in some countries fewer and fewer people are interested in selfless activity for social organizations. In others, the number of volunteers is not a problem, but the main difficulties are related to the aspirations of the new generations of volunteers, rather than a drop in the number of volunteers (for example inadequate knowledge of the needs of organizations, the difficulty in matching volunteers with appropriate organizations, preference for short rather than long-term voluntary commitments).

Non-governmental organizations operating in market conditions, like all other entities, must have financial resources enabling them to achieve their goals, maintain a paid platform, etc. These often turn out to be insufficient, which is one of the main reasons for non-profit organizations starting in business. Its consequences are the subject of a wide discussion, one of the research directions being tensions resulting in non-profit commissioning. This also applies to volunteering. The attitude of volunteers towards being a substitute for paid employees is not always favorable. The retention of volunteers is also associated with significant organizational costs. The current state of the literature quite extensively describes the relationship between government activity and volunteering, while the effects of commercial revenue raising have still not been broadly researched.

The results of this research indicate that in the case of NGOs conducting business activity, a statistically significant higher level of volunteering in general can be observed. This also applies to occasional volunteering, i.e. volunteers involved at least once in the organization's activities in the last 12 months. In addition, the analysis points to a statistically higher number of volunteers who during the last 12 months have been engaged in the work of an organization regularly and often, i.e. undertook activities for the organization at least once a month. Therefore, the research has confirmed the hypothesis that the commercialization of Polish NGOs can be associated with a crowding in effect on volunteering.

The crowding in phenomenon is conducive to offering potential volunteers internal training conducted by people from the organization. However, while offering volunteers the acquisition of knowledge inside the organization is interesting for them and encourages free work, enabling participation in conferences works in the opposite direction, causing a weakening of the volunteer's involvement. It can be said that the direction of knowledge transfer (inside or outside the organization through, for example, conferences) can be crucial in engaging volunteer work in NGOs. The results of this study may confirm some process theory assumptions that indicate the effect of internal and external types of motivation. In this context, numerous researchers explain that the motivation of volunteers is not only due to altruism and a pro-social attitude, but is also influenced by a group of factors derived from the interior of the organization, its management and culture. This is indicated by the Person-Environment model, which includes compliance of work, mission and strategy, as well as compliance with a group of colleagues and superiors (Nascimento et al., 2018; Bright, 2005).

The discussion on the impact of the commercialization of NGOs on volunteering requires further research. It is necessary to identify the importance of other factors that motivate volunteers to become more involved in an organization's activities, including in the longer term. 


\section{Compliance with Ethical Standards}

Conflict of Interest We declare that We have no conflict of interest.

We declare that the article has not been financed by grants, funds, etc. and does not require any permission from any organization.

We declare that our contribution to the work is as follows (table below) and there is no conflict of interest between authors.

Open Access This article is licensed under a Creative Commons Attribution 4.0 International License, which permits use, sharing, adaptation, distribution and reproduction in any medium or format, as long as you give appropriate credit to the original author(s) and the source, provide a link to the Creative Commons licence, and indicate if changes were made. The images or other third party material in this article are included in the article's Creative Commons licence, unless indicated otherwise in a credit line to the material. If material is not included in the article's Creative Commons licence and your intended use is not permitted by statutory regulation or exceeds the permitted use, you will need to obtain permission directly from the copyright holder. To view a copy of this licence, visit http://creativecommons.org/licenses/by/4.0/.

\section{References}

Andreoni, J., \& Payne, A. A. (2011). Is crowding out due entirely to fundraising? Evidence from a panel of charities. Journal of Public Economics, 95(5-6), 334-343.

Austin, J., Stevenson, H., \& Wei-Skillern, J. (2006). Social and commercial entrepreneurship: Same, different or both? Entrepreneurship Theory and Practice, 30, 1-22.

Barr, A., Fafchamps, M., \& Owens, T. (2005). The governance of non-governmental organizations in Uganda. World Development, 33(4), 657-679.

Bartels, K. P., Cozzi, G., \& Mantovan, N. (2013). The big society, public expenditure, and volunteering. Public Administration Review, 73(2), 340-351.

Boschee, J. (1998). Merging Mission and Money: A Board Member's Guide to Social Entrepreneurship. Retrieved from: http://www.socialenterprisecanada.ca/en/learn/nav/resourcelibrary.html?page= resourceDe.

Bright, L. (2005). Public employees with high levels of service motivation: Who are they, where are they, and what do they want? Review of Public Personnel Motivation, 25(2), 138-154. https://doi.org/10.1177 /0734371X04272360.

Cordery, C., \& Tan, L. (2010). A survey of the effects of direct financial costs in volunteering. Third Sector Review, 16(1), 105-124.

D’Espallier, B., Hudon, M., \& Szafarz, A. (2017). Aid volatility and social performance in microfinance. Nonprofit and Voluntary Sector Quarterly, 46(1), 116-140.

Dart, R. (2004). The legitimacy osf social Enterprise. Nonprofit Management and Leadership, 14(4), 41-424.

Day, K. M., \& Rose A. D. (1996). Volunteerism and crowding out: Canadian econometric evidence. Canadian Journal of Economics, 29(1), 37-53.

Dreyfus, S. N. (2018). Volunteerism and US civil society. In Standford social innovation review Retrieved from https://ssir.org/articles/entry/volunteerism_and_us_civil_society.

Duncan, B. (1999). Modeling charitable contributions of time and money. Journal of Public Economics, $72(2), 213-242$.

Ebrahim, A. (2003). Accountability in practice: Mechanisms for NGOs. World Development, 31, 813-829.

Ebrahim, A., Battilana, J., \& Mair, J. (2014). The governance of social enterprises: Mission drift and accountability challenges in hybrid organizations. Research in Organizational Behavior, 34, 81-100.

Eikenberry, A. M., \& Kluver, J. D. (2004). The marketization of the nonprofit sector: Civil society at risk? Public Administration Review, 64(2), 132-140.

Enjolras, B. (2002). The commercialization of voluntary sport organizations in Norway. Nonprofit and Voluntary Sector Quarterly, 31(3), 352-376.

Evans, B., Richmond, T., \& Shields, J. (2005). Structuring neoliberal governance: The nonprofit sector, emerging new modes of control and the marketisation of service delivery. Policy and Society, 24(1), 7397.

Foster, W., \& Bradach, J. (2005). Should nonprofits seek profits? Harvard Business Review, 83(2), 92-100. 
Foster, M. K., \& Meinhard, A. G. (2002). A contingency view of the responses of voluntary social service organizations in Ontario to government cutbacks. Canadian Journal of Administrative Sciences, 19(1), $27-41$.

Ganesh, S., \& McAllum, K. (2012). Volunteering and professionalization: Trends in tension? Management Communication Quarterly, 26(1), 152-158.

Geoghegan, M., \& Powell, F. (2006). Community development, partnership governance and dilemmas of professionalization: Profiling and assessing the case of Ireland. British Journal of Social Work, 36, 845861.

Gordy, J. (2015). Volunteering is at a 10-Year Low. What Can We Do About It?, NeonCRM, Retrieved from: https://www.neoncrm.com/volunteer-management-solutions/).

Graff, L. (2006). Declining profit margin: When volunteers cost more that they return. International Journal of Volunteer Administration, 24(1), 24-32.

Guo, B. (2006). Charity for profit? Exploring factors associated with the commercialization of human service nonprofits. Nonprofit and Voluntary Sector Quarterly, 35, 123-138.

Hackl, F., Halla, M., \& Pruckner, G. J. (2012). Volunteering and the state. Public Choice, 151, 465-495.

Handy, F., \& Srinivasan, N. (2005). The demand for volunteer labor: A study of hospital volunteers. Nonprofit and Voluntary Sector Quarterly, 34, 491-509.

Handy, F., \& Mook, L. (2011). Volunteering and volunteers: Benefit-cost analyses. Research on Social Work Practice, 21(4), 412-420.

Herman, R. D., \& Rendina, D. (2001). Donor reactions to commercial activities of nonprofit organizations: An American case study. International Journal of Voluntary and Nonprofit Organizations, 12, 157-169.

Hopkins, S. (2002). VET and the voluntary sector: Dealing with ambiguities. Centre for the Economics of Education and Training: Victoria, Australia.

Huntley, R. (2019). Volunteering benefits our community and society, but rates are declining. In $A B C$ life Retrieved from https://www.abc.net.au/life/benefits-of-volunteering-to-community-andsociety/11075998.

Katsarova, I. (2016). Volunteering in the EU. In European Parliament Retrieved from: http://www.europarl. europa.eu/RegData/etudes/ATAG/2016/589841/EPRS_ATA(2016)589841_EN.pdf.

Kerlin, J. A., \& Pollak, T. (2006). Nonprofit commercial revenue: A replacement for declining government grants and private contributions? United Kingdom Social Enterprise Research Conference, London: Paper presented at the Third Annual.

Kerlin, J. A., \& Pollak, T. H. (2011). Nonprofit commercial revenue: A replacement for declining government grants and private contributions? American Review of Public Administration, 41, 686-704.

Liu, G., \& Ko, W. W. (2012). Organizational learning and marketing capability development: A study of the charity retailing operations of British social enterprise. Nonprofit and Voluntary Sector Quarterly, 41, 580-608.

Maier, F., Meyer, M., \& Steinbereithner, M. (2016). Nonprofit organizations becoming business-like a systematic review. Nonprofit and Voluntary Sector Quarterly, 45(1), 64-86.

Manetti, G., Bellucci, M., Como, E., \& Bagnoli, L. (2014). Investing in volunteering: Measuring social returns of volunteer recruitment, training, and management. Voluntas, 26(5), 2104-2129.

Marshall, J. H., \& Suárez, D. (2013). The flow of management practices: An analysis of NGO monitoring and evaluation dynamics. Nonprofit and Voluntary Sector Quarterly, 43(6), 1033-1051.

McKay, S., Moro, D., Teasdale, S., \& Clifford, D. (2015). The marketisation of charities in England and Wales. Voluntas: International Journal of Voluntary and Nonprofit Organizations, 26(1), 336-354.

Mikołajczak, P. (2020). Social enterprises' hybridity in the concept of institutional Logics: Evidence from Polish NGOs. Voluntas. https://doi.org/10.1007/s11266-020-00195-9.

Mikołajczak, P. (2019). Becoming business-like: The determinants of NGOs' marketization turning into social enterprises in Poland. Oeconomia Copernicana, 10(3), 537-559.

Mikołajczak, P. (2018). The impact of the diversification of revenues on NGOs' commercialization: Evidence from Poland. Equilibrium. Quarterly Journal of Economics and Economic Policy, 13(4), 761-779.

Mook, L., Handy, F., \& Quarter, J. (2007). Reporting volunteer labour at the organizational level: A study of Canadian non-profits. Voluntas: International Journal of Voluntary \& Nonprofit Organizations, 18, 5571.

Nascimento, T. T., Porto, J. B., \& Kwantes, C. T. (2018). Transformational leadership and follower proactivity in a volunteer workforce. Nonprofit Management and Leadership, 28(4), 565-576.

Powell, W. W., \& Owen-Smith, J. (1998). Universities and the market for intellectual property in the life sciences. Journal of Policy Analysis and Management, 17, 253-277.

Rosen, H. S. \& Sims S.T.(2011). Altruistic behavior and habit formation. Nonprofit Management and Leadership, 21(3), 235-253. https://doi.org/10.1002/nml.20023 
Royce, M. (2007). Using human resource management tools to support social enterprise: Emerging themes from the sector, Social Enterprise Journal, 3(1), 10-19.

Sajardo, A., \& Serra, I. (2011). The economic value of volunteer work: Methodological analysis and application to Spain. Nonprofit and Voluntary Sector Quarterly, 40(5), 873-895.

Salamon, L. M. (1987). Of market failure, voluntary failure, and third-party government: The theory of government-nonprofit relations in the modern welfare state. Journal of Voluntary Action \& Research, 16, 29-49.

School of Public Policy (2018).Where are America's Volunteers? A Look at America's Widespread Decline in Volunteering in Cities and States, Retrieved from https://dogood.umd.edu/sites/default/files/201907 /Where\%20Are\%20Americas\%20Volunteers_Research\%20Brief\%20_Nov\%202018.pdf.

Simmons, W. O., \& Emanuele, R. (2004). Does government spending crowd out donations of time and money? Public Finance Review, 32(5), 498-511.

Simpson, M., \& Cheney, G. (2007). Marketization, participation, and communication within New Zealand retirement villages: A critical-rhetorical and discursive analysis. Discourse \& Communication, 1(2), 191122.

Smith, W. K., \& Lewis, M. W. (2011). Toward a theory of paradox: A dynamic equilibrium model of organizing. Academy of Management Review, 36(2), 381-403.

Suzuki, K. (2017). Government expenditure cuts and voluntary activities of citizens: The experience of Japanese municipalities. Asia Pacific Journal of Public Administration, 39(4), 258-275.

Tuckman, H. P. (1998). Competition, commercialization, and the evolution of nonprofit organizational structures. Journal of Policy Analysis and Management, 17, 175-194.

Turcotte, M. (2015). Volunteering and charitable giving in Canada, spotlight on Canadians: Results from the general social survey. In Canada Retrieved from https:/www150.statcan.gc.ca/n1/en/pub/89-652-x/89652-x2015001-eng.pdf?st=9od0kNw9.

Van Oorschot, W., \& Arts, W. (2005). The social capital of European welfare states: The crowding out hypothesis revisited. Journal of European Social Policy, 15, 5-26.

Weisbrod, B. A. (1997). The future of the nonprofit sector: Its entwining with private enterprise and government. Journal of Public Policy Analysis and Management, 16(4), 541-555.

Publisher's Note Springer Nature remains neutral with regard to jurisdictional claims in published maps and institutional affiliations.

Pawel Mikolajczak prof. PUEB, dr hab. - employee of the Department of Money and Banking at the Poznań University of Economics. His research interests relate to the nonprofit sector, social enterprises as well as innovation and competitiveness of SME. He is a member of the Research Team for the Management of Non Profit Organizations at PUEB, the Polish Association of Finance and Banking and the Polish Economic Society. He is the author of numerous scientific articles. He has many years of economic experience. He specializes in financial and investment consulting for enterprises and nonprofit organizations. An expert in the field of European funds for the SME sector.

Piotr Bajak dr - member of the Polish Economic Society. He is the author of numerous scientific articles. His interests are focused in particular on social enterprises as well as financial instruments, mainly bonds. He has many years of economic experience. He specializes in analyzing the efficiency of enterprises and processes of creating company value. 